\title{
An Analysis of Income Sensitivity to Social Technology: A Comparison among Country Groups Using Panel Data
}

\author{
CHUL-KYU KANG ${ }^{* *}$ AND JAE-HYUNG LEE ${ }^{* * *}$
}

Using available panel data on 68 countries covering the years 1998-2006, we measure the sensitivity of per capita real GDP to change in each of the five social technologies by six country groups: OECD, Asia NIEs, developing countries, BRICs, less-developed countries, and Korea. The regression results suggest that each of the five social technologies in this paper (i.e., anti-corruption, deregulation, property rights, government size, and law) is positively related to per capita real GDP. The regression results also suggest that per capita real GDP is more elastic with respect to each of the five social technologies than IT as a proxy for physical technology in the groups of relatively rich countries. It is evident that per capita real GDP is elastic with respect to social technologies in Korea. This implies that to speed up Korea's advancement, improving social technology may be crucial.

Keywords: Social Technology, A Comparison among Country Groups

JEL Classification: C51, O43, P16.

The authors would like to thank the two anonymous referees for their comments in improving the paper. This work was supported by University of Seoul during the sabbatical year.

- Corresponding Author. School of Economics, University of Seoul; Tel: +82-2-2210-2512;

E-mail: ckkang@uos.ac.kr.

The Brain Korea 21, Department of Economics, Seoul National University. Seoul National University,

San 56-1, Shillim-Dong, Kwanak-Gu, Seoul, 151-746, Korea; Tel: +82-2-880-4061:

E-mail: jhlee2000@snu.ac.kr. 


\section{INTRODUCTION}

C

iting Easterly and Levine's work (2003), Beinhocker (2006) argues that while the existence of natural resources, the competence of government policies, and the relative sophistication of a country's physical technologies all matter to a degree, the real driver of increased productivity is the state of a nation's social technology. He defines social technologies as methods and designs for organizing people in pursuit of a goal or goals. This social technology broadly includes 'institutions' indicators such as property rights, rule of law, a well-organized banking system, economic transparency, and lack of corruption.

In the last twenty years the literature about social capital, which promotes the efficiency for economic development, has increased exponentially in economics and sociology. These studies, originally based on institutions, tend to include organizations as a concept of social capital (Castiglione et al. 2008). In this study, social technology includes not only social capital but also operational capabilities which make, manage, and revise both institutions and organizations. On the basis of this, we have incorporated anti-corruption in items of social technologies, such as deregulation, property rights, government size and the rule of law (Guctat 2006). 1

Social technology affects economic performance through productivity growth. Productivity differences are great among countries. Productivity is increased by social and physical technologies. The major part of productivity differentials is due to the differences in social technologies.

Employing the cross-country panel data for 68 countries over the years 1998 2006, we measure the sensitivity of per capita real GDP to change in each of social technologies by six country groups: OECD, Asia NIEs, developing countries (DCs), BRICs, less-developed countries (LDCs), and South Korea (hereafter Korea). After the grouping, we obtain the elasticity of per capita real GDP with respect to each of the social technology variables. Based on a comparative analysis by six country groups, we compare the beneficial effects of social technologies on per capita real GDP in Korea, as well as in the five country groups.

\section{ANALYTICAL FRAMEWORK}

In order to measure the sensitivity of per capita real GDP to change in each of the social technologies by the six country groups, the structural equation on per capita real GDP is defined by

$$
\mathrm{Y}_{u t}=\sum_{j=1}^{10} \mathrm{a}_{j} \mathrm{D}_{j} * \mathrm{X}_{j t-1}+\text { Error }
$$


where $\mathrm{Y}_{t}$ denotes per capita real GDP converted with Purchasing Power Parity. $D_{1}$ is classified as group OECD, composed of 26 countries. $D_{2}$ is classified as group Asia NIEs such as Hong Kong, Indonesia, Malaysia, Philippines, Singapore, and Thailand (Chowdhury and Lyanatul 1993). $D_{3}$ is classified as group DCs that are composed of 13 countries, $\mathrm{D}_{4}$ is classified as group BRICs (Brazil, Russia, India, China), and $D_{3}$ is classified as group LDCs that are composed of 18 countries. $D_{6}$ indicates Korea. $D_{3}$ and $D_{5}$ are classified in terms of the mean value of per capita real GDP over nine years $(\$ 5,178)$.

From equation (1) the elasticity of per capita real GDP with respect to each of the explanatory variables including social technologies can be obtained. A higher elasticity is associated with a higher per capita real GDP, suggesting that each of the explanatory variables should be strengthened.

The coefficient on $\mathrm{D}_{6}$ which indicates Korea is equal to the value of the constant term. Therefore, in order to avoid the problem of multi-collinearity and to measure the elasticity of per capita real GDP with respect to each of the explanatory variables, including social and physical technologies by six country groups, we rely on OLS regression through the origin (Wooldridge 2000).

Vector $\mathrm{X}_{\text {tt. }}$ includes the following variables: anti-corruption (ACPI), business, credit and labor deregulation (DEREG), property rights (PR), the size of government (NONGOVT), the rule of law (LAW), rate of internet users (IT), current account balance (CA), foreign direct investment inflow (FDI), education (ED), and health (H).

Table 1 provides a description of the variables used in the model as well as their means and standard deviation (SD). Details of the data sources are also given in Table 1 .

\section{DATA}

Each of the five social technology variables in the above model implies a positive effect. As such, a higher value in the variable will be associated with a relatively higher level of each of the five social technology indicators. Each indicator has a value between 0 and 100. To facilitate interpretation of the results the size of government (NONGOVT) is transformed into 100 minus the original values. The transformed value implies a positive effect, so that a higher value will be associated with a relatively higher level of NONGOVT.

IT (the number of internet users per one hundred in a population) is measured as a proxy for physical technology. ${ }^{2}$ We have dealt with the functional form issue using the Pearson correlation coefficient between dependent and explanatory variables and have found the linear transformation suitable.

The groups of countries are classified by per capita real GDP. The mean values of per capita real GDP by six country groups during the period of 1998 2006 are summarized in Table 2. 
TABle I. Definition of Variables

\begin{tabular}{|c|c|c|c|}
\hline Variables & Definition & $\begin{array}{c}\text { Mean } \\
(\mathrm{SD})\end{array}$ & $\begin{array}{c}\text { Maximum } \\
\text { (Minimum) }\end{array}$ \\
\hline$Y^{\prime \prime}$ & $\begin{array}{l}\text { Per Capita Gross Domestic Product Converted } \\
\text { with Purchasing Power Parity }\end{array}$ & $\begin{array}{l}12.979 \\
(10.618)\end{array}$ & $\begin{array}{l}41.890 \\
(0.480)\end{array}$ \\
\hline $\mathrm{ACPI}^{2 !}$ & Anti-Corruption Perception Index & $\begin{array}{r}49.752 \\
(21.153)\end{array}$ & $\begin{array}{l}100.000 \\
(10.000)\end{array}$ \\
\hline DEREG & Business, Credit and Labor Deregulation Index & $\begin{array}{l}62.026 \\
(10.251)\end{array}$ & $\begin{array}{r}87.600 \\
(31.800)\end{array}$ \\
\hline $\mathrm{PR}^{4}$ & Property Right Index & $\begin{array}{l}58.879 \\
(23.230)\end{array}$ & $\begin{array}{c}90.000 \\
(10.000)\end{array}$ \\
\hline NONGOVT" & The Size of Government & $\begin{array}{l}37.869 \\
(24.142)\end{array}$ & $\begin{array}{l}100.000 \\
(5.900)\end{array}$ \\
\hline $\mathrm{LANW}^{6 !}$ & The Rule of Law & $\begin{array}{c}60.697 \\
(27.418)\end{array}$ & $\begin{array}{l}100.000 \\
(1.905)\end{array}$ \\
\hline $\mathrm{IT}^{*}$ & Rate of Internet Users & $\begin{array}{l}22.283 \\
(22.893)\end{array}$ & $\begin{array}{l}86.000 \\
(0.000)\end{array}$ \\
\hline$C A^{x i}$ & Current Account Balance & $\begin{array}{l}-3.169 \\
(65.362)\end{array}$ & $\begin{array}{l}172.070 \\
(-791.504)\end{array}$ \\
\hline $\mathrm{FDI}^{\prime \prime}$ & Foreign Direct Investment inflow & $\begin{array}{c}4.772 \\
(10.313)\end{array}$ & $\begin{array}{l}76.512 \\
(-2.555)\end{array}$ \\
\hline $\mathrm{ED}^{(\theta)}$ & Education Index & $\begin{array}{c}85.488 \\
(13.468)\end{array}$ & $\begin{array}{l}99.300 \\
(9.800)\end{array}$ \\
\hline$H^{11}$ & Life Expectancy at Birth & $\begin{array}{c}69.486 \\
(11.450)\end{array}$ & $\begin{array}{c}82.000 \\
(36.500)\end{array}$ \\
\hline $\mathrm{POP}^{121}$ & Population & $\begin{array}{c}72.829 \\
(200.271)\end{array}$ & $\begin{array}{c}1307.560 \\
(1.348)\end{array}$ \\
\hline
\end{tabular}

NOTES: 1), 8), 9). In thousand U.S. dollars.

2), 3), 4), 5), 6), 10), Scale of 0 to 100.

5) NONGOVT indicates 100-GOVT (the government expenditure divided by GDP), Unit: \%.

7) The number of internet users per one hundred in a population.

11) Unit: years

12) In one million people.

SOURCES: 1), 10), 11), 12), UNDP. Human Development Report 2007/2008.

2) Transparency International.

3) The Fraser Institute. The Economic Freedom of the World Project.

4), 5) The Heritage Foundation, index of Economic Freedom.

6) World Economic Forum, Global Competitiveness Report.

7) The World Bank Group. World Development Indicators.

8) UN, International Trade Statistics Yearbook.

9) UNCTAD, UN. World Investment Report 2006.

Table 2. The mean of Per Capital. Real. Gdp by Country Groups During THE PERIOD OF $1998 \sim 2006$

\begin{tabular}{c|c|c|c|c|c}
\hline OECD & Asia NIEs & DCs & BRICs & LDCs & Korea \\
\hline 22.474 & 12.380 & 9.020 & 5.438 & 2.403 & 16.967 \\
\hline
\end{tabular}

NOTES: In thousand U.S. dollars. 


\section{ESTIMATION RESULTS}

In Table 3, each of the five social technology variables (i.e., anti-corruption, business deregulation, property rights, government size, and the rule of law), IT as a proxy for physical technology, foreign direct investment inflows, and human capital such as education and health is positively related to per capita real GDP.

The regression results also suggest per capita real GDP is relatively more elastic with respect to each of variable of anti-corruption, business deregulation, property rights, the size of government, the rule of law, education, and health in OECD and Korea, whereas per capita real GDP is relatively less elastic with respect to each variable of anti-corruption, business deregulation, the property rights, the size of government, the rule of law, education, and health in the other countries. ${ }^{3}$ An implication of this is that social technology is more sensitive to economic growth in OECD and Korea.

On the other hand, the regression results suggest that per capita real GDP is more elastic with respect to each of five social technology variables than IT in the groups of relatively rich country groups such as OECD, Asia NIEs, and Korea, whereas it is more elastic with respect to IT than social technology variables in the groups of relatively poor country groups such as developing countries (DCs), BRICs, and less-developed countries (LDCs). This suggests that social technology is relatively more influential with per capita real GDP than IT in relatively rich countries.

A comparison of each of the social technology and IT elasticities of per capita real GDP is in line with the McKinsey Global Institute (2001). The institute found that the real driver of increased U.S. productivity during the period of 1995 2000 changed in how companies were organizing and managing themselves; in other words, improvement in social technologies. IT was only one of a number of factors that led to significant productivity growth.

In Korea, per capita real GDP is elastic with respect to social technology variables with one exception (i.e., property rights). It is also evident that Korea has a greater elasticity of per capita real GDP with respect to social technology improvement than to physical technology in a positive value. This may be due to the fast development of the IT sector (the IT elasticity of growth among physical capital inputs may be greater than average), and the relatively slow improvement of social technology in Korea. This implies that the improvement of social technology is more important than IT for Korea's future economic growth. Therefore, to speed up Korea's advancement, improvement of social technology should be strengthened.

\section{CONCLUSION}

In order to measure the sensitivity of per capita real GDP to change in each 
table 3. The Ceteris Paribus Mean Elastictty of Per Capital. Real. Gdp With Respect to Each of Explanatory Variables by Country Group: The Pooled ols estimates ${ }^{11}$

\begin{tabular}{|c|c|c|c|c|c|c|c|c|c|}
\hline \multirow{2}{*}{$\begin{array}{c}\text { Explanatory } \\
\text { Variables }\end{array}$} & \multicolumn{6}{|c|}{ Country Group } & \multirow{2}{*}{ Adjusted $\mathrm{R}^{2}$} & \multirow{2}{*}{ Joint $\mathrm{F}$} & \multirow{2}{*}{ SEE } \\
\hline & OECD & Asia NIEs & DCs & BRICs & LDCs & Korea & & & \\
\hline ACPI & $\begin{array}{c}1.196 \\
(0.004)\end{array}$ & $\begin{array}{c}0.997 \\
(0.010)\end{array}$ & $\begin{array}{l}0.721 \\
(0.008)\end{array}$ & $\begin{array}{c}0.644 \\
(0.022\}\end{array} \cdots$ & $\begin{array}{c}0.310 \\
(0.011)^{\cdots}\end{array}$ & $\begin{array}{c}1.457 \\
(0.033)\end{array} \cdots$ & 0.936 & $\begin{array}{c}(6,538)= \\
1316.873 \cdots\end{array}$ & 4.038 \\
\hline DEREG & $\begin{array}{l}1.582 \\
(0.005)\end{array}$ & $\begin{array}{c}0.941 \\
(0.011)\end{array} \cdots$ & $\begin{array}{c}0.683 \\
(0.008)\end{array} \cdots$ & $\frac{0.507}{(0.018)} \cdots$ & $\begin{array}{c}0.196 \\
(0.008)\end{array}$ & $\begin{array}{c}1.386 \\
(0.032)\end{array} \cdots$ & 0.898 & $\begin{array}{c}(6.534)= \\
794.587\end{array}$ & 5.095 \\
\hline PR & $\begin{array}{c}1.293 \\
(0.004)\end{array}$ & $\begin{array}{c}0.984 \\
(0.010)\end{array} \cdots$ & $\begin{array}{c}0.721 \\
(0.008)\end{array} \ldots$ & $\begin{array}{c}0.549 \\
(0.019)\end{array} \cdots$ & $\begin{array}{c}0.245 \\
(0.0(09)\end{array} \cdots$ & $\begin{array}{c}0.930 \\
(0.020)\end{array} \cdots$ & 0.922 & $\begin{array}{c}(6,538)= \\
1073.657\end{array}$ & 4.440 \\
\hline NONGOVT & $\begin{array}{c}0.989 \\
(0.008)\end{array}$ & $\begin{array}{c}2.264 \\
(0.079)\end{array} \cdots$ & $\begin{array}{c}0.659 \\
(0.018)\end{array}$ & $\begin{array}{c}0.601 \\
(0.047)\end{array} \ldots$ & $\begin{array}{c}0.239 \\
(0.023)\end{array} \cdots$ & $\begin{array}{l}2.399 \\
(0.127) \cdots\end{array}$ & 0.799 & $\begin{array}{c}(6,538)= \\
360.599 \cdots\end{array}$ & 7.138 \\
\hline LAW & $\begin{array}{c}1.225 \\
(0.003)\end{array}$ & $\begin{array}{c}1.010 \\
(0.009)\end{array}$ & $\begin{array}{c}0.711 \\
(0.007)\end{array} \cdots$ & $\begin{array}{c}0.500 \\
(0.108)\end{array}$ & $\begin{array}{c}0.290 \\
(0.010)^{\cdots}\end{array}$ & $\begin{array}{c}1.066 \\
(0.021)\end{array}$ & 0.926 & $\begin{array}{c}(6,538)= \\
11\{2.850\end{array}$ & 4.314 \\
\hline IT & $\begin{array}{c}0.828 \\
(0.009)\end{array}$ & $\begin{array}{c}0.781 \\
(0.026)\end{array}$ & $\begin{array}{c}0.719 \\
(0.030)\end{array}$ & $\begin{array}{c}0.864 \\
(0.098)\end{array} \ldots$ & $\begin{array}{c}0.658 \\
(0.080))\end{array} \cdots$ & $\begin{array}{c}0.469 \\
(0.034)\end{array} \cdots$ & 0.875 & $\begin{array}{c}(6,538)= \\
637.437 \cdots\end{array}$ & 5.617 \\
\hline$C A$ & $\begin{array}{l}-0.011 \\
(0.010)\end{array}$ & $\begin{array}{c}0.273 \\
(0.184)\end{array} \cdots$ & $\begin{array}{l}-0.050 \\
(0.319)\end{array}$ & $\begin{array}{c}0.018 \\
(0.064)\end{array}$ & $\begin{array}{c}0.007 \\
(0.732)\end{array}$ & $\begin{array}{c}0.155 \\
(0.249)\end{array}$ & 0.098 & $\begin{array}{l}(6,538)= \\
10.797 \cdots\end{array}$ & 15.110 \\
\hline FDI & $\begin{array}{l}0.513 \\
(0.058)\end{array}$ & $\begin{array}{c}0.179 \\
(0.053)\end{array}$ & $\begin{array}{c}1.433 \\
(0.467) \cdots\end{array}$ & $\begin{array}{c}3.949 \\
(3.652)\end{array}$ & $\begin{array}{l}1.993 \\
(2.102)^{* *}\end{array}$ & $\begin{array}{c}4.328 \\
(2.730)\end{array} \ldots$ & 0.581 & $\begin{array}{l}(6,538)= \\
126.962 \cdots\end{array}$ & 10.290 \\
\hline ED & ${ }_{(0.004)}^{1.522} \ldots$ & $\begin{array}{c}0.942 \\
(0.010)\end{array}$ & $\begin{array}{c}0.678 \\
(0.006)\end{array}$ & $\begin{array}{c}0.461 \\
(0.012)\end{array} \cdots$ & $\frac{0.224}{(0.006)^{2}} \ldots$ & $\begin{array}{c}1.120 \\
(0.021)\end{array}$ & 0.875 & $\begin{array}{l}(6.538)= \\
634.135 \cdots\end{array}$ & 5.630 \\
\hline $\mathrm{H}$ & $\begin{array}{c}1.526 \\
(0.005)^{\circ .}\end{array}$ & $\begin{array}{c}0.926 \\
(0.011)\end{array}$ & $\begin{array}{c}0.701 \\
(0.008)\end{array}$ & $\begin{array}{c}0.418 \\
(0.014)\end{array}$ & $\begin{array}{c}0.230) \\
(0.008)\end{array}$ & $\begin{array}{c}1.140 \\
(0.026)\end{array}$ & 0.879 & $\begin{array}{l}(6.538)= \\
657.430\end{array}$ & 5.541 \\
\hline
\end{tabular}

NOTES: 1) Obtained at mean value. For example, the ceteris paribes elasticity (3) of per capita real GDP with respect to each of explanatory variables can be obtained as Given $Y=a_{0}+a_{1} X, 3=a_{1} \times(X)$

$Y_{m a n}$ and $X_{\text {mem }}$ denote mean values of $Y$ and $X$ from $\langle$ Table $1>$, respectively.

Values in parentheses are the estimated standard errors of the regression coefficients. $\cdots . \cdots$, and ${ }^{*}$ indicate significance at the levels of $1 \%, 5 \%$, and $10 \%$ on two-tailed test, respectively. Each of the observed joint F-statistic is greater than the 99 per cent critical value, suggesting that the null hypothesis of coefficient instability is rejected. 
of the five social technologies (i.e., anti-corruption, business deregulation, property rights, the size of government, and the rule of law) by six country groups, we utilized available panel data on 68 countries classified into six groups (OECD, Asia NIEs, Developing Countries, BRICs, Less-Developed Countries, and Korea) covering the years 1998-2006. The overall results and analysis of the estimated models allow for the following concluding remarks to be made regarding the propositions tested:

First, each of the five social technologies and IT as a proxy for physical technology is positively related to per capita real GDP.

Second, per capita real GDP is more elastic with respect to each of the five social technologies in the OECD group and Korea than in the other countries. An implication of this is that social technology is more sensitive to economic growth in the OECD group and Korea.

Third, per capita real GDP is more elastic with respect to each of the five social technologies than IT in the groups of relatively rich country groups such as the OECD, Asia NIEs, and Korea, whereas it is more elastic with respect to IT than each of the five social technologies in the groups of relatively poor country groups such as DCs, BRICs, and LDCs. This suggests that social technology is relatively more influential with per capita real GDP than IT in relatively rich countries.

It is also evident that Korea has a greater elasticity of per capita real GDP with respect to social technology improvement than to IT. This may be due to the fast development of the IT sector (the IT elasticity of growth among physical capital inputs may be greater than average), and the relatively slow improvement of social technology in Korea. This implies that social technology improvement is very important for Korea's future economic growth. To speed up Korea's advancement, social technology improvement might be crucial.

\section{REFERENCES}

Barro, R. J. and J. W. Lee. 2000. International Data on Educational Attainment Updates and Implications. Working Paper 7911, NBER.

Barro, R. J. and X. Sala-i-Martin. 2001. Economic Growth. Cambridge: MIT Press.

Beinhocker, E. D. 2006. The Origin of Wealth: Evolution, Complexity, and the Radical Remaking of Economics. Boston, MA: Harvard Business School Press and Random House.

Borensztein, E., J. D. Gregoriob, and J-W. Lee. 1998. How Does Foreign Direct Investment Affect Economic Growth?. Journal of International Economics 45(1): 115-135.

Castiglione, D., W. R. D. Jan, and W. Guglielmo. 2008. The Handbook of Social 
Capital. Oxford: Oxford University Press.

Chowdhury, A. and I. Lyanatul. 1993. The Newly Industrialising Economies of East Asia. New York: Routledge.

Durham, J. B. 2004. Absorptive Capacity and the Effects of Foreign Direct Investment and Equity Foreign Portfolio Investment on Economic Growth. European Economic Review 48(2): 285-306.

Easterly, W. and R. Levine. 2003. Tropics, Germs, and Crops: How endowments Influence Economic Development. Journal of Monetary Economics S0(1): 3-39.

Guetat I. 2006. The effects of corruption on growth performance of the MENA countries. Journal of Economics and Finance 30(2): 208-221.

Hanushek, E. and D. Kimko. 2000. Schooling, Labor-Force Quality, and the Growth of Nations. American Economic Review 90(5): 1184-1208.

Krugman, P. R. and M. Obstfeld 2008. International Economics: Theory and Policy 8th Ed. Addison Wesley: Pearson Education.

Moulton, B. R. 1999. GDP and the Digital Economy: Keeping up with the Changes. unpublished manuscript.

Shastry, G. K. and D. N. Weil. 2003. How Much of Cross-Country Income Variation is Explained by Health? Journal of the European Economic Association 1(2): 387-96.

Wooldridge, J. M. 2000. Introductory Econometrics: A Mlodern Approach. Boston, MA: South-Western College Publishing. 


\section{APPENDIX}

appendix table 1. Pearson Correlation Coefficients (and Associated P-Values) FOR EAch of SOCIal. TeChNology Variables and IT ${ }^{1 !}$

\begin{tabular}{|c|c|c|c|c|c|c|}
\hline Variables & ACPI & DEREG & PR & NONGOVT & LAW & IT \\
\hline $\mathrm{ACPI}$ & 1 & $\begin{array}{c}0.688 \\
(0.000)\end{array}$ & $\begin{array}{c}0.874 \\
(0.000)\end{array}$ & $\begin{array}{c}0.573 \\
(0.000)^{\cdots}\end{array}$ & $\begin{array}{c}0.903 \\
(0.000)\end{array} \ldots$ & $\begin{array}{c}0.784 \\
(0.000)\end{array}$ \\
\hline DEREG & $\begin{array}{c}0.688 \\
(0.000)\end{array}$ & 1 & $\begin{array}{c}0.628 \\
(0.000)\end{array}$ & $\begin{array}{c}0.222 \\
(0.000)\end{array}$ & $\begin{array}{c}0.623 \\
(0.000)\end{array}$ & $\begin{array}{c}0.600 \\
(0.000)^{\cdots}\end{array}$ \\
\hline PR & $\begin{array}{c}0.874 \\
(0.000)\end{array}$ & $\begin{array}{c}0.628 \\
(0.000)\end{array}$ & 1 & $\begin{array}{c}0.509 \\
(0.000)\end{array}$ & $\begin{array}{c}0.894 \\
(0.000)\end{array}$ & $\begin{array}{c}0.705 \\
(0.000)^{\cdots .}\end{array}$ \\
\hline NONGOVT & $\begin{array}{c}0.573 \\
(0.000)\end{array} \cdots$ & $\begin{array}{c}0.222 \\
(0.000)\end{array} \ldots$ & $\begin{array}{c}0.509 \\
(0.000)\end{array} \cdots$ & 1 & $\begin{array}{c}0.598 \\
(0.000)\end{array}$ & $\begin{array}{c}0.524 \\
(0.000)^{\cdots}\end{array}$ \\
\hline LAW & $\left.\begin{array}{c}0.903 \\
(0.000)\end{array}\right)^{\cdots}$ & $\begin{array}{c}0.623 \\
(0.000)\end{array} \ldots$ & $\begin{array}{c}0.894 \\
(0.000)\end{array} \ldots$ & $\begin{array}{c}0.598 \\
(0.000)\end{array} \cdots$ & 1 & $\begin{array}{c}0.742 \\
(0.000)\end{array} \ldots$ \\
\hline IT & $\begin{array}{c}0.784 \\
(0.000)\end{array} \ldots$ & $\begin{array}{c}0.600 \\
(0.000)\end{array} \cdots$ & $\begin{array}{c}0.705 \\
(0.000)\end{array}$ & $\begin{array}{c}0.524 \\
(0.000)\end{array} \ldots$ & $\begin{array}{c}0.742 \\
(0.000)\end{array} \ldots$ & 1 \\
\hline
\end{tabular}

NOTES: 1) ${ }^{\cdots}$ indicates significance at the $1 \%$ level on a two-tailed test. The number of observations (n) $=54$. 
Appendix Table 2. The Effect of ACPI on Y: PoOled Ols"

\begin{tabular}{|c|c|c|c|c|c|}
\hline \multirow{2}{*}{$\begin{array}{c}\text { Explanatory } \\
\text { Variables }\end{array}$} & \multicolumn{5}{|c|}{ DependentVariable: $Y$} \\
\hline & $\mathrm{OECD}^{21}$ & Asia NIEs & DCs & BRICs & L.DCs \\
\hline ACPI & $\begin{array}{c}0.112 \\
(0.016)\end{array}$ & $\begin{array}{c}0.101 \\
(0.037)^{\cdots}\end{array}$ & $\begin{array}{c}0.071 \\
(0.023)^{\cdots}\end{array}$ & $\begin{array}{c}0.131 \\
(0.038) \cdots\end{array}$ & $\begin{array}{c}0.044 \\
(0.009) \cdots \\
\end{array}$ \\
\hline $\mathrm{CA}$ & $\begin{array}{c}-0.020 \\
(0.002)^{\cdots} \\
\end{array}$ & $\begin{array}{c}0.069 \\
(0.043)\end{array}$ & $\begin{array}{c}-0.115 \\
(0.061)^{\circ}\end{array}$ & $\begin{array}{c}0.010 \\
(0.004)\end{array}$ & $\begin{array}{c}0.050 \\
(0.041) \\
\end{array}$ \\
\hline FDI & $\begin{array}{c}0.229 \\
(0.030)\end{array}$ & $\begin{array}{c}0.082 \\
(0.025)^{\cdots}\end{array}$ & $\begin{array}{c}1.095 \\
(0.296)^{\cdots}\end{array}$ & $\begin{array}{c}1.215 \\
(0.675)^{\circ}\end{array}$ & $\begin{array}{l}-0.217 \\
(0.321) \\
\end{array}$ \\
\hline ED & $\begin{array}{l}-0.047 \\
(0.035) \\
\end{array}$ & $\begin{array}{c}0.003 \\
(0.069) \\
\end{array}$ & $\begin{array}{c}0.035 \\
(0.076)\end{array}$ & $\begin{array}{c}0.139 \\
(0.014)^{\cdots}\end{array}$ & $\begin{array}{c}0.034 \\
(0.006)^{\cdots \cdot} \\
\end{array}$ \\
\hline $\mathrm{H}$ & $\begin{array}{c}1.433 \\
(0.119)^{\cdots}\end{array}$ & $\begin{array}{c}0.842 \\
(0.236) \cdots \\
\end{array}$ & $\begin{array}{c}0.086 \\
(0.044)^{\circ}\end{array}$ & $\begin{array}{c}-0.261 \\
(0.047)^{\cdots}\end{array}$ & $\begin{array}{c}0.062 \\
(0.007)^{\cdots}\end{array}$ \\
\hline $\begin{array}{l}\text { Year dummies } \\
\text { Included }\end{array}$ & Yes & Yes & Yes & Yes & Yes \\
\hline Constant & $\begin{array}{c}-91.994 \\
(8.612)^{\cdots}\end{array}$ & $\begin{array}{c}-55.357 \\
(16.492) \cdots\end{array}$ & $\begin{array}{l}-5.664 \\
(5.542) \\
\end{array}$ & $\begin{array}{c}8.261 \\
(1.891) \cdots\end{array}$ & $\begin{array}{c}-4.936 \\
(0.556)^{\cdots}\end{array}$ \\
\hline $\mathrm{R}^{2}$ & 0.824 & 0.981 & 0.577 & 0.477 & 0.735 \\
\hline Adjusted R2 & 0.814 & 0.975 & 0.521 & 0.962 & 0.711 \\
\hline $\mathrm{F}$ & $\begin{array}{l}(12,203)= \\
79.215\end{array}$ & $\begin{array}{l}(12,35)= \\
151.583 \cdots\end{array}$ & $\begin{array}{l}(12,91)= \\
10.351 \cdots\end{array}$ & $\begin{array}{l}(12.19)= \\
66.142 \cdots\end{array}$ & $\begin{array}{l}(12,131)= \\
30.302 \cdots\end{array}$ \\
\hline D.W. & 0.422 & 1.335 & 0.493 & 1.825 & 0.375 \\
\hline SEE & 3.395 & 1.510 & 2.713 & 0.474 & 0.782 \\
\hline $\mathrm{N}$ & 216 & 48 & 104 & 32 & 144 \\
\hline
\end{tabular}

NOTES: 1)..Values in parentheses are the estimated absolute standard errors of the regression coefficient. , and indicate significance at the levels of $1 \%, 5 \%$, and $10 \%$ on a two-tailed test, respectively. We review previous studies on the effects of factors which influence the level of economic growth such as the use of information technology. current account balance, foreign direct investment inflow, human capital (education and health), and find their marginal contributions to be substantial. See, e.g., Moulton, 1999; Krugman and Obstfeld, 2008; Barro and Sala-i-Martin, 2001: Durham, 2004; Borensztein et al., 1998; Hanushek and Kimko, 2000; Barro and Lee, 2000; Shastry and Weil, 2003.

On the other hand, each of the social technology variables and IT are highly correlated. Therefore, to avoid the possibility of multi-collinearity, IT was omitted from the pooled OLS regressions (see <Appendix Table $1>$ ).

The pooled of OLS estimations report that ED (education) is not significantly related to $Y$ (per capita real GDP). This suggests that ED and $H$ (health) are highly correlated; the Pearson Correlation Coefficient (and associated p-value) for ED and $\mathrm{H}$ appears to be $0.740(0.000) ; n=544$. Excluding $\mathrm{H}$ from the estimation, more education leads to higher per capita real GDP.

2). Included Korea. 
Appendix Table 3. The Effect of Dereg on Y: Pooled Ols"

\begin{tabular}{|c|c|c|c|c|c|}
\hline \multirow{2}{*}{$\begin{array}{c}\text { Explanatory } \\
\text { Variables }\end{array}$} & \multicolumn{2}{|r|}{ Dependent } & \multicolumn{2}{|l|}{ Variable: $\mathrm{Y}$} & \multirow[b]{2}{*}{ LDCs } \\
\hline & $\mathrm{OECD}^{21}$ & Asia NIEs & DCs & BRICs & \\
\hline DEREG & $\begin{array}{c}0.136 \\
(0.036)^{\cdots}\end{array}$ & $\begin{array}{c}0.021 \\
(0.050)\end{array}$ & $\begin{array}{l}-0.029 \\
(0.044)\end{array}$ & $\begin{array}{c}0.009 \\
(0.032)\end{array}$ & $\begin{array}{c}0.003 \\
(0.010)\end{array}$ \\
\hline CA & $\begin{array}{c}.0 .019 \\
(0.003)^{\cdots}\end{array}$ & $\begin{array}{c}0.114 \\
(0.046)\end{array}$ & $\begin{array}{c}-0.162 \\
(0.068)^{*}\end{array}$ & $\begin{array}{c}0.002 \\
(0.004)\end{array}$ & $\begin{array}{c}0.034 \\
(0.043)\end{array}$ \\
\hline FDI & $\begin{array}{c}0.283 \\
(0.030)^{\cdots}\end{array}$ & $\begin{array}{c}0.050 \\
(0.025)^{\circ}\end{array}$ & $\begin{array}{c}1.776 \\
(0.259)^{\cdots *}\end{array}$ & $\begin{array}{c}2.893 \\
(0.613)^{\cdots}\end{array}$ & $\begin{array}{l}0.139 \\
(0.323)\end{array}$ \\
\hline ED & $\begin{array}{l}-0.018 \\
(0.037)\end{array}$ & $\begin{array}{c}0.044 \\
(0.074)\end{array}$ & $\begin{array}{l}-0.031 \\
(0.076)\end{array}$ & $\begin{array}{c}0.112 \\
(0.017)^{\cdots}\end{array}$ & $\begin{array}{c}0.032 \\
(0.006)^{\cdots}\end{array}$ \\
\hline $\mathrm{H}$ & $\begin{array}{c}1.761 \\
(0.111)^{\cdots}\end{array}$ & $\begin{array}{c}1.370 \\
(0.155)^{\cdots}\end{array}$ & $\begin{array}{c}0.062 \\
(0.053)\end{array}$ & $\begin{array}{c}-0.113 \\
(0.030)^{\cdots}\end{array}$ & $\begin{array}{c}0.073 \\
(0.007)^{\cdots}\end{array}$ \\
\hline $\begin{array}{c}\text { Year dummies } \\
\text { included }\end{array}$ & Yes & Yes & Yes & Yes & Yes \\
\hline Constant & $\begin{array}{l}-123.198 \\
(7.499)^{\cdots}\end{array}$ & $\begin{array}{c}-93.395 \\
(9.620)^{\cdots}\end{array}$ & $\begin{array}{l}5.699 \\
(6.203)\end{array}$ & $\begin{array}{c}2.916 \\
(3.641)\end{array}$ & $\begin{array}{c}-4.038 \\
(0.832)^{\cdots}\end{array}$ \\
\hline $\mathrm{R}^{2}$ & 0.798 & 0.977 & 0.537 & 0.962 & 0.724 \\
\hline Adjusted $\mathrm{R}^{2}$ & 0.786 & 0.969 & 0.476 & 0.938 & 0.698 \\
\hline $\mathrm{F}$ & $\begin{array}{l}(12,203)= \\
66.796 \cdots\end{array}$ & $\begin{array}{c}(12,35)= \\
124.735 \cdots\end{array}$ & $\begin{array}{l}(12,91)= \\
8.794^{\cdots}\end{array}$ & $\begin{array}{l}(12,19)= \\
40.214^{\cdots}\end{array}$ & $\begin{array}{c}(12,127)= \\
27.715\end{array}$ \\
\hline D.W. & 0.447 & 1.114 & 0.538 & 1.223 & 0.333 \\
\hline SEE & 3.638 & 1.661 & 2.839 & 0.603 & 0.809 \\
\hline $\mathrm{n}$ & 216 & 48 & 104 & 32 & 140 \\
\hline
\end{tabular}

NOTES: 1), 2). Sec Appendix Table 2. 
Appendix Table 4. The Effect of PR on Y: PoOled Ols ${ }^{11}$

\begin{tabular}{|c|c|c|c|c|c|}
\hline \multirow{2}{*}{$\begin{array}{c}\text { Explanatory } \\
\text { Variables }\end{array}$} & \multicolumn{2}{|r|}{ Dependent } & \multicolumn{2}{|l|}{ Variable: $Y$} & \multirow[b]{2}{*}{ LDCs } \\
\hline & $\mathrm{OECD}^{2 i}$ & Asia NIEs & DCs & BRICs & \\
\hline PR & $\begin{array}{c}0.202 \\
(0.020)^{\cdots}\end{array}$ & $\begin{array}{l}-0.041 \\
(0.037)\end{array}$ & $\begin{array}{c}0.020 \\
(0.020)\end{array}$ & $\begin{array}{c}0.030 \\
(0.020)\end{array}$ & $\begin{array}{c}0.011 \\
(0.006)^{\circ}\end{array}$ \\
\hline $\mathrm{CA}$ & $\begin{array}{c}-0.017 \\
(0.002)^{\cdots}\end{array}$ & $\begin{array}{c}0.130 \\
(0.048)^{\cdots}\end{array}$ & $\begin{array}{c}-0.135 \\
(0.064)^{*}\end{array}$ & $\begin{array}{c}0.009 \\
(0.006)\end{array}$ & $\begin{array}{c}0.023 \\
(0,044)\end{array}$ \\
\hline FDI & $\begin{array}{c}0.185 \\
(0.027)^{\cdots}\end{array}$ & $\begin{array}{c}0.055 \\
(0.025) \cdot *\end{array}$ & $\begin{array}{c}1.489 \\
(0.315) \cdots\end{array}$ & $\begin{array}{c}2.922 \\
(0.541)^{\cdots}\end{array}$ & $\begin{array}{c}0.204 \\
(0.333)\end{array}$ \\
\hline ED & $\begin{array}{l}-0.057 \\
(0.031)^{\circ}\end{array}$ & $\begin{array}{c}0.096 \\
(0.084)\end{array}$ & $\begin{array}{l}-0.019 \\
(0.077)\end{array}$ & $\begin{array}{c}0.114 \\
(0.014) \cdots\end{array}$ & $\begin{array}{c}0.035 \\
(0.007)^{\cdots}\end{array}$ \\
\hline $\mathrm{H}$ & $\begin{array}{c}1.433 \\
(0.099)^{\cdots}\end{array}$ & $\begin{array}{c}1.531 \\
(0.166)^{\cdots}\end{array}$ & $\begin{array}{c}0.085 \\
(0.046)^{\circ}\end{array}$ & $\begin{array}{c}-0.102 \\
(0.027)^{\cdots}\end{array}$ & $\begin{array}{c}0.066 \\
(0.007)^{\cdots}\end{array}$ \\
\hline $\begin{array}{c}\text { Year dummies } \\
\text { included }\end{array}$ & Yes & Yes & Yes & Yes & Yes \\
\hline Constant & $\begin{array}{l}-98.019 \\
(6.862) \cdots\end{array}$ & $\begin{array}{c}-105.189 \\
(12.636)\end{array}$ & $\begin{array}{l}0.691 \\
(5.551)\end{array}$ & $\begin{array}{l}1.011 \\
(2.551)\end{array}$ & $\begin{array}{c}-4.509 \\
(0.701)^{\cdots}\end{array}$ \\
\hline $\mathrm{R}^{2}$ & 0.857 & 0.978 & 0.539 & 0.966 & 0.693 \\
\hline Adjusted $\mathrm{R}^{2}$ & 0.849 & 0.970 & 0.479 & 0.944 & 0.665 \\
\hline $\mathrm{F}$ & $\begin{array}{l}(12,203)= \\
101.391 \cdots\end{array}$ & $\begin{array}{l}(12.35)= \\
128.638 \cdots\end{array}$ & $\begin{array}{l}(12,91)= \\
\text { s.882 } \cdots\end{array}$ & $\begin{array}{l}(12,19)= \\
41.831 \cdots\end{array}$ & $\begin{array}{l}(12,131)= \\
2+.607 \cdots\end{array}$ \\
\hline D.W. & 0.461 & 1.048 & 0.508 & 1.313 & 0.292 \\
\hline SEE & 3.060 & 1.636 & 2.832 & 0.573 & 0.842 \\
\hline$n$ & 216 & 48 & 104 & 32 & 144 \\
\hline
\end{tabular}

NOTES: 1), 2). See Appendix Table 2. 
Appendix Table 5. The Effect of Nongovt on Y: Pooled Ols ${ }^{11}$

\begin{tabular}{|c|c|c|c|c|c|}
\hline \multirow{2}{*}{$\begin{array}{c}\text { Explanatory } \\
\text { Variables }\end{array}$} & \multicolumn{2}{|r|}{ Dependent } & \multicolumn{2}{|l|}{ Variable: Y } & \multirow[b]{2}{*}{ LDCs } \\
\hline & $\mathrm{OECD}^{2)}$ & Asia NIEs & DCs & BRICs & \\
\hline NONGOVT & $\begin{array}{c}0.050 \\
(0.013)^{\cdots}\end{array}$ & $\begin{array}{c}0.065 \\
(0.063)\end{array}$ & $\begin{array}{c}0.073 \\
(0.014)^{\cdots}\end{array}$ & $\begin{array}{c}0.049 \\
(0.022)\end{array}$ & $\begin{array}{l}-0.005 \\
(0.006)\end{array}$ \\
\hline $\mathrm{CA}$ & $\begin{array}{c}-0.025 \\
(0.002)\end{array}$ & $\begin{array}{c}0.099 \\
(0.045)^{*}\end{array}$ & $\begin{array}{c}-0.152 \\
(0.056) \cdots\end{array}$ & $\begin{array}{c}0.006 \\
(0.004)\end{array}$ & $\begin{array}{c}0.032 \\
(0.045)\end{array}$ \\
\hline FDI & $\begin{array}{c}0.304 \\
(0.029)^{\cdots}\end{array}$ & $\begin{array}{c}0.053 \\
(0.025)\end{array}$ & $\begin{array}{c}1.439 \\
(0.210)^{\cdots}\end{array}$ & $\begin{array}{c}2.937 \\
(0.511)^{\cdots}\end{array}$ & $\begin{array}{c}0.373 \\
(0.330)\end{array}$ \\
\hline ED & $\begin{array}{c}0.011 \\
(0.066)\end{array}$ & $\begin{array}{c}0.077 \\
(0.078)\end{array}$ & $\begin{array}{l}-0.105 \\
(0.069)\end{array}$ & $\begin{array}{c}0.091 \\
(0.016)^{\cdots}\end{array}$ & $\begin{array}{c}0.029 \\
(0.007)^{\cdots}\end{array}$ \\
\hline $\mathrm{H}$ & $\begin{array}{c}1.824 \\
(0.118)^{\cdots}\end{array}$ & $\begin{array}{c}1.424 \\
(0.126) \cdots\end{array}$ & $\begin{array}{c}0.127 \\
(0.042)^{\cdots}\end{array}$ & $\begin{array}{l}-0.030 \\
(0.046)\end{array}$ & $\begin{array}{c}0.067 \\
(0.008) \cdots\end{array}$ \\
\hline $\begin{array}{c}\text { Year dummies } \\
\text { included }\end{array}$ & Yes & Yes & Yes & Yes & Yes \\
\hline Constant & $\begin{array}{l}-124.158 \\
(7.430)\end{array}$ & $\begin{array}{c}-99.465 \\
(9.786) \cdots\end{array}$ & $\begin{array}{c}3.705 \\
(4.357)\end{array}$ & $\begin{array}{l}-2.231 \\
(3.206)\end{array}$ & $\begin{array}{c}-3.631 \\
(0.553) \cdots\end{array}$ \\
\hline $\mathrm{R}^{2}$ & 0.801 & 0.978 & 0.637 & 0.970 & 0.687 \\
\hline Adjusted $\mathrm{R}^{2}$ & 0.789 & 0.970 & 0.589 & 0.950 & 0.658 \\
\hline $\mathrm{F}$ & $\begin{array}{c}(12,203)= \\
68.095 \cdots\end{array}$ & $\begin{array}{l}(12,35)= \\
127.921 \cdots\end{array}$ & $\begin{array}{l}(12,91)= \\
13.322 \cdots\end{array}$ & $\begin{array}{l}(12,19)= \\
50.470 \cdots\end{array}$ & $\begin{array}{c}(12.131)= \\
23.914 \cdots\end{array}$ \\
\hline D.W. & 0.414 & 1.201 & 0.689 & 1.281 & 0.304 \\
\hline SEE & 3.610 & 1.641 & 2.513 & 0.541 & 0.851 \\
\hline $\mathrm{n}$ & 216 & 48 & 104 & 32 & 144 \\
\hline
\end{tabular}

NOTES: 1), 2). See Appendix Table 2. 
Appendix Table 6. The Effect of Law on Y: Pooled Ols ${ }^{11}$

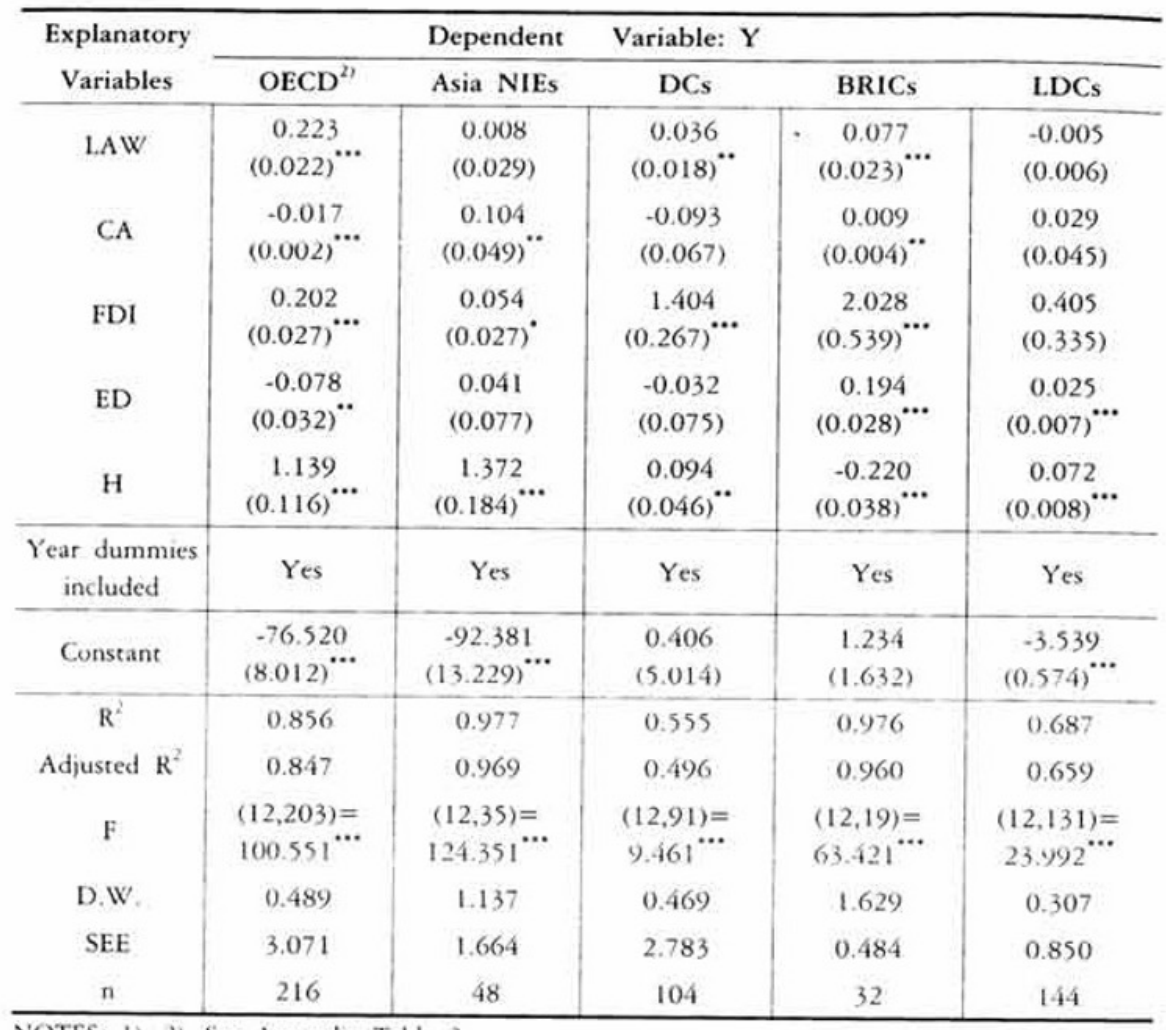

NOTES: 1), 2), See Appendix Table 2. 


\section{ENDNOTES}

1 Corporate governance and transparency-increasing disclosure are also incorporated in items of social technologies. However, we cannot measure the ceteris paribus mean elasticity of per capita real GDP with respect to each of the corporate governance and transparency-increasing disclosure because of the data limitations.

2 The number of patents cannot be used as a proxy for physical technology because of data limitations.

The pooled ordinary least squares (OLS) results suggest that anti-corruption, business deregulation, property rights, government size, and the rule of law are important determinants of economic growth by country groups (see, e.g., Appendix Table 2-Appendix Table 6). The estimated Pearson correlation coefficientssuggest that five sucial technology variables are highly correlated (Appendix Table 1). Therefore, social technology variables are included in separate regressions. 